\title{
Primary neuroendocrine breast carcinomas: a retrospective analysis and review of literature [Corrigendum]
}

\author{
Yang X, Cao YD, Chen C, Liu L, Wang C, Liu SC. \\ OncoTargets and Therapy. 2017;10:397-407.
}

On page 398, Patients and methods section, Patients subheading, the last sentence read "This study was approved by the ethics committee from The First Affiliated Hospital of Chongqing Medical University, who deemed written informed consent not necessary due to the retrospective nature of the research". However, the sentence should have been "This study was approved by the ethics committee from The First Affiliated Hospital of Chongqing Medical University, who deemed written informed consent not necessary due to the retrospective nature of the research and that patient consent was implied for the patients who were contacted during the study that provided additional data".
OncoTargets and Therapy

\section{Publish your work in this journal}

OncoTargets and Therapy is an international, peer-reviewed, open access journal focusing on the pathological basis of all cancers, potential targets for therapy and treatment protocols employed to improve the management of cancer patients. The journal also focuses on the impact of management programs and new therapeutic agents and protocols on

\section{Dovepress}

patient perspectives such as quality of life, adherence and satisfaction. The manuscript management system is completely online and includes a very quick and fair peer-review system, which is all easy to use. Visit http://www.dovepress.com/testimonials.php to read real quotes from published authors. 